\title{
BIBLIOGRAFIA ESPECIALIZADA NA ÁREA DE COMUNICAÇÃO E EDUCAÇÃO
}

\section{TELEVISÃO E EDUCAÇÃo}

ROCCO, Maria Thereza Fraga. "A televisão como agente educativo". In: LEAL FILHO, Laurindo. (org.). 20 anos de TV pública em São Paulo. São Paulo: ECA/USP, 1989, p.15-25. (Simpósio de Comunicações e Artes;2)

Analisa as especificidades do veículo televisivo com relação às propostas educativas. Ressalta a necessidade de uma interlocução real com o receptor da TV Cultura, de forma a torná-la efetivamente uma televisão pública.

Loc.Doc.: ECA-USP [791.45 Leal Filho]

\section{RECEPÇÃO CRÍTICA}

GOMES, Pedro Gilberto. "O projeto de leitura crítica da UCBCl". In: Estratégia para um melhor uso dos meios de comunicação para a educação dos grupos de populações desfavorecidos: a participação dos receptores. São Paulo: OREALC; Intercom, 1986, p.34-41.

Discute questões relacionadas com a leitura crítica dos meios de comunicação tendo em vista a função educativa de denúncia da manipulação. Destaca a experiência com grupos populares.

Loc.Doc.: INTERCOM ${ }^{2}$

\section{TEATRO E EDUCAÇÃO}

CARLI, Ênio Borba. Jornalismo científico e o ensino de ciências no Brasil: a utilização de notícias no ensino de biologia, física e química no segundo grau. São Bernardo do Campo: IMS / SBC. 
Discute a inclusão da ciência contemporânea no ensino de ciências em cursos do segundo grau. Destaca que a atenção aos meios de comunicação de massa e aos noticiários podem levar os alunos a fazerem uma avaliação social da ciência e da tecnologia.

Loc.Doc.: IMS - Instituto Metodista de Ensino ${ }^{3}$

\section{LITERATURA E EDUCAÇÃO}

BONAZZI, Mariza, ECO, Humberto. Mentiras que parecem verdades. São Paulo: Summus, 1980.

Estudo sobre os livros usados na escolas italianas. Os autores concluem que os fatos, os conceitos e os valores contidos nessas obras educativas, além de serem desatualizados, camuflam o caráter de classe da sociedade e induzem a um conformismo com os padrões vigentes. Glorificando a pobreza, enaltecendo a pátria e mitificando o trabalhador, o livro didático mente ao educando. Por isso mesmo é que os autores concluem por sugerir aos educadores o uso de outros materiais (jornais, quadrinhos, livros de aventura) na sala de aula, atualizando assim o processo de aprendizado formal.

Loc.Doc.: ECA-USP [371.32E19m]

\section{MEIOS DE COMUNICAÇÃO DE MASSA E DE EDUCAÇÃo}

FADUL, Anamaria. Estratégia para um melhor uso dos meios de comunicação para a educação dos grupos de populações desfavorecidos: a participação dos receptores. Coordenação de Anamaria Fadul. São Paulo: OREALC/ INTERCOM, 1986.

Discute o livro e sua relação com as camadas pobres da população. Descreve o projeto IDAC na busca de uma linguagem adequada para o livro, de forma que ele sirva como ferramenta para a discussão coletiva, o estímulo e a referência para a ruptura com os mecanismos de opressão.

Loc.Doc.: ECA-USP [301.161 F146N]

NEUMANN, Laurindo. Educação e comunicação alternativa. Petrópolis: Vozes, 1990. 76p.

Discute a situação dos meios de comunicação de massa (MCM) no Brasil e a ideologia desses meios que se caracteriza pelo controle da sociedade através da manipulação de informações e distorção dos fatos. Analisa a função da comunicação alternativa, popular e comunitária, em oposição à comunicação de massa. Estuda a educação e a comunicação alternativa como sendo os meios que propiciam aos indivíduos a possibilidade de compreender a realidade em que vivem, sem os artifícios usados pelos meios de comunicação de massa.

Loc.Doc.: ECA-USP [301.16 Neumann] 
SANTORO, Luís Fernando. "O rádio e a televisão como objetos de ensino". In: Educação e comunicação de massas. Revista de Cultura Vozes. Petrópolis: ano 74, Vol. LXXIV (7), 513-518, setembro de 1980.

Modos de intervenção social através dos MCM quebrando o caráter unilateral da emissão e pensando numa educação cujo objetivo principal seja formar a consciência crítica dos receptores. Sugere linhas para a execução do projeto.

\section{EDUCAÇÃo PARA A COMUNICAÇÃo}

FREIRE, Paulo e outros. Vivendo e aprendendo. São Paulo: Brasiliense, 1980.

Repertório de experiências do IDAC, organização que Paulo Freire criou no exílio, no campo da educação popular. Além dos estudos de Rosiska e Miguel Darcy de Oliveira sobre a prática educativa na Guiné Bissau ou a experiência com operários italianos, há um capítulo que interessa de perto aos estudiosos da comunicação: o depoimento de Claudius Ceccon sobre uma nova linguagem da comunicação social - o humor.

Loc.Doc.: ECA-USP [370 V857]

GUARANYS, Lúcia Radlier dos, CASTRO, Cláudio de Moura. O ensino por correspondência: uma estratégia de desenvolvimento educacional no Brasil.

Rio de Janeiro: IPEA, 1980.

Estudo sobre as vantagens pedagógicas e econômicas do ensino por correspondência. Os autores tomam como ponto de referência as experiências estrangeiras, mas analisam também os projetos em curso no Brasil.

LOC.DOC: FEA-USP ${ }^{4}$ [374.481 G914E] 